\title{
The problem of training of future teachers of physical education for organization of competitive activities in the field of professional education
}

\section{Проблема підготовки майбутніх учителів фізичної культури до організації змагальної діяльності у сфері професійної освіти}

\author{
Kashuba Anatolii \\ Кашуба Анатолій \\ Lesya Ukrainka Eastern European National University, Lutsk, Ukraina
}

Keywords: professional training; competitive activities; future teachers; physical education Ключові слові: професійна підготовка; змагальна діяльність; майбутні учителі; фізична культура

\begin{abstract}
Using theoretical analysis of scientific and methodological literature on the problem of a study, it has been revealed and reasoned in the article certain factors which affect the training process of future teachers of physical education for professional work and stated that the present requirements for professional competence of a teacher, its theoretical and practical training become more expressed and must be aimed at the development of a teacher's personality with such qualities that would meet the current requirements of the present time and ensure success of practical activity. It has been revealed and described abilities that must be mastered by the future teachers of physical education for the successful implementation of their professional activity, and skills required for the successful organization of competitive activities on sport games. It has been defined that the future teacher of physical education must be prepared for teaching, educational, scientific an methodological, organizational and supervisory activities in the system of secondary education according to the obtained specialty, where the typical kinds of its activities are as follows: educational, health and fitness, sports, organizational, recreation and preventive activities and include: planning physical education process; organizing and conducting physical education lessons; conducting educational and training lessons, organizing sports classes work, training school teams for competitive activities; promoting healthy lifestyles and monitoring the level of health and physical fitness of students; development of own professional level, summing up and implementing advanced experience of work.
\end{abstract}




\begin{abstract}
Анотація
За допомогою теоретичного аналізу науково-методичної літератури з проблеми дослідження у статті розкрито та обгрунтовано окремі чинники, які негативно впливають на процес підготовки майбутніх учителів фізичної культури до професійної діяльності та констатували, що сучасні вимоги до професійної компетентності учителя, його теоретична та практична підготовка набувають більш вираженого характеру та мають бути спрямовані на формування особистості педагога 3 такими якостями, які відповідали б наявним вимогам сьогодення і забезпечували успішність практичної діяльності. Розкрито та охарактеризовано вміння, якими мають оволодіти майбутні учителі фізичної культури для успішної реалізації їх професійної діяльності, а також навички, які необхідні для успішної організації змагальної діяльності зі спортивних ігор. Визначено, що майбутній учитель фізичної культури має бути підготовлений до викладацької, навчально-виховної, науково-методичної та організаційно-керівної діяльності у системі середньої освіти відповідно до отриманої спеціальності, де типовими видами його діяльності є: навчально-виховна, фізкультурно-оздоровча, спортивна, організаційна та рекреаційно-профілактична робота і включають у себе: планування процесу фізичного виховання; організацію і проведення уроків фізичної культури; проведення навчально-тренувальних занять, організацію секційної роботи, підготовку шкільних команд до змагальної діяльності; пропагування здорового способу життя та контроль за рівнем здоров'я і фізичної підготовки учнів; підвищення власного професійного рівня, узагальнення та впровадження передового досвіду роботи
\end{abstract}

\title{
Постановка проблеми.
}

На сучасному етапі розвитку освіти підготовка майбутніх учителів є одним із основних завдань, сформульованих в Державній національній програмі «Освіта. Україна XXI століття» (1993), «Концепції виховання дітей та молоді в національній системі освіти» (1996), «Концепції гуманітарної освіти України на період до 2020 року» (2011), де модернізація вітчизняної системи освіти, що здійснюється в контексті ідеї безперервної освіти передбачається і нові підходи до формування особистості майбутніх фахівців[10, с. 37].

У новій цільовій соціальній програмі розвитку фізичної культури і спорту на період до 2020 року також обумовлюється необхідність внесення певних змін у процес підготовки майбутніх учителів фізичної культури в системі вищої педагогічної освіти, практична діяльність яких, повинна бути спрямована на виховання у молодого покоління здорового способу життя, профілактики захворювань, формування гуманістичних цінностей, створення умов для всебічного гармонійного розвитку людини, сприяння досягненню фізичної та духовної досконалості людини, виявлення резервних можливостей організму, формування патріотичних почуттів у громадян та позитивного іміджу держави у світовому співтоваристві[11].

За останні роки помітно зріс інтерес до вивчення ролі і місця фізичної культури в системі вищої освіти, переглядаються сформовані раніше підходи, що знаходить своє відповідне висвітлення в змісті нового освітнього стандарту, нових навчальних планах i програмах, пошуку шляхів удосконалення професійної підготовки майбутніх учительських кадрів [3, с. 103].

\section{Аналіз останніх досліджень та публікацій.}

Проблема професійної підготовки майбутнього педагога є досить актуальною в теорії та практиці вищої школи, а іiї вивчення почалося ще в 50-ті роки минулого століття (Р. Уайт, 1959; В. Заціорський, 1966; Л. Матвєєва, 1968; А. Новікова, 1968; Н. Хомський, 1972; Б. Ашмарин, 1979; В. Афанасєв, 1980; Н. Кузьміна, 1982; та ін.), де професійна підготовка розглядалася як певний рівень розвитку особи: усвідомлення поставленого завдання; вироблення плану та регулювання майбутніх 
дій; відповідно до поставленої мети застосування засобів і прийомів діяльності; співставлення отриманих результатів із вихідними умовами[15, с.222].

В подальшому теоретичні та методичні засади професійної підготовки майбутніх учителів фізичної культури у вищих навчальних закладах розглядали вітчизняні вчені Б. А. Ашмарін, Р. П. Карпюк, Т. Ю. Круцевич, Г. М. Арзютова,

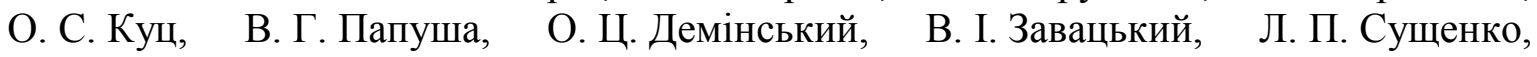
Б. М. Шиян, Ю. М. Шкребтій та ін.; а також російські вчені С. П. Євсєєв, Г. А. Степанова, М. Я. Віленський, Б. Ф. Курдюков, В. Ф. Костюченко, В. В. Кузін, Л. Е. Варфоломеєва, А. М. Новіков та ін.; професійні особливості діяльності вчителя фізичної культури досліджували Л.О.Демінська, Л.І.Іванова, С. І. Присяжнюк, Л. П. Сущенко, І. С. Якиманська та ін.; удосконалення фізичних якостей учнів у роботі вчителя фізичної культури вивчали Р. Ф. Ахметов, В. М. Гостіщев, А. В. Сватьєв, Н. В. Богдановська, М. О. Козленко, Г. В. Рощупкін та ін.

\section{Мета статті/Методи дослідження}

Мета статті - здійснити теоретичний аналіз проблеми підготовки майбутніх учителів фізичної культури у педагогічній теорії та практиці до організації змагальної діяльності зі спортивних ігор у школі. Методи дослідження - теоретичний аналіз наукової, методичної та спеціальної літератури, узагальнення передового досвіду учителів фізичної культури.

\section{Виклад основного матеріалу дослідження.}

Інноваційні підходи до вдосконалення вищої фізкультурної освіти відображені в роботах В. Платонова (2001, 2008, 2009), О. Вацеби (2001), А. Цьося (2005), Ю. Шкребтія (2004, 2006), М. Дутчака $(2009,2010,2012)[1$, с. 13], де розглядаючи професійну підготовку майбутнього педагога та його професійну діяльність, у тому числі вчителя фізичної культури, вони звертають увагу, передусім, на її зміст, тому що він несе в собі певну сукупність знань умінь і навичок, володіння якими дає змогу працювати спеціалістам на високому методичному рівні.

Проблема професійної підготовки майбутніх учителів фізичної культури постійно знаходиться в полі зору спеціальних науково-дослідних установ, наукових колективів та окремих дослідників, оскільки лише за останні роки в Україні було проведено низку науково-практичних конференцій присвячених виключно цій проблемі, або це питання обговорювалося поряд з іншими напрямками наукових досліджень.

У психолого-педагогічній літературі проблема професійної підготовки майбутніх учителів фізичної культури до практичної діяльності в загальноосвітньому навчальному закладі має багатоаспектне теоретичне висвітлення[12, с. 209].

Методолого-теоретичні й навчально-методичні аспекти професійної підготовки майбутніх фахівців у педагогічному навчальному закладі III-IV рівнів акредитації розглядалися вченими (А. М. Алексюком, Н. В. Кузьміною, А. М. Бойко, Б. В. Годом, О.Я. Савченко, О. В. Сухомлинською, Н. М. Дем'яненко та ін.). Дидактичні основи загальної середньої і вищої педагогічної освіти розроблено у працях (Я. Я. Болюбаша, В. Стрельнікова, Н. І. Шиян, В. І. Бондаря, В. О. Огнев'юка, Л. М. Кравченко та ін.).

Концептуальні засади підготовки майбутніх фахівців фізичного виховання та спорту обгрунтовано у працях вітчизняних науковців (А. В. Цьось, Е. С. Вільчковський, Л. О. Демінська, Б. М. Шиян, М. О. Носко, Л. П. Сущенко, та ін.) і ряду зарубіжних дослідників (Г. Бабушкін, В. Байдак, В. Головін, В. Ільїніч, Т. Колгуріна, В. Корецький, А. Кузьмін, Г. Шашкінта ін.). Формування спеціальної компетентності та готовності майбутніх учителів фізичної культури до професійної 
діяльності досліджували такі вчені, як В. Байдак, О. Богініч, Г. Генсерук, М. Данилко, Н. Зубанова, Р. Карпюк, В. Наумчук, В. Смолюк. Окремі чинники підготовки майбутнього учителя розглядали О. Д. Дубогай, О. А. Ахвердова, В. П. Горащук, В. І. Бобрицька та ін.; розробці моделей підготовки фахівців фізичної культури присвятили свої роботи А. Ц. Демінський, В. М. Мазін, О. А. Свєртнєв та ін.; підготовки фахівців зі спортивних ігор Л.В.Волков, Г. І. Максименко, І. Б. Верблюдов, В. А. Бабаліч та ін.; готовності до професійної діяльності майбутніх учителів фізичної культури - Л.В.Богданова, Р. П. Карпюк, О.В.Онопрієнко та ін.[13, с. 6].

Це дало змогу констатувати, що у системі підготовки майбутніх учителів фізичної культури з' явилося багато протиріч, серед яких Л. Г. Чернишова виділяє такі: суспільство не повною мірою задоволено результатом і якістю роботи навчальних закладів з підготовки фахівців; багато випускників не відповідають своєму статусу, не виправдовують соціальних очікувань, не можуть вирішити завдання виховання фізично і психічно здорового молодого покоління; очевидний розрив між ступенем підготовленості майбутніх учителів фізичної культури до роботи в нових соціально-економічних умовах i зростаючими запитами суспільства де реальною стає загроза професійної некомпетентності [14, с. 95].

Так, П. І. Канівець розглядає якість фахівця як об'єктивно існуючу сукупність властивостей і характеристик (знання, уміння, навички, особистісні якості, здібності, комунікативні та інші якості), яка визначає його як фахівця певної професії та спеціальності й відрізняє його від інших спеціалістів. Якість підготовки фахівця, на думку дослідника, це сукупність суттєвих властивостей та характеристик фахівця, рівень яких формується в процесі здійснення освітньої діяльності й повинен відповідати вимогам споживачів. Автор виділяє наступні проблеми підготовки майбутніх фахівців:

- Проблема невідповідності структури знань, умінь у молодих фахівців виробничим вимогам унаслідок розриву раніше існуючих системних зв'язків між виробництвом, наукою й освітою.

- Проблема оцінки рівня конкурентоспроможності підготовки фахівців і виявлення чинників його підвищення.

- Проблема невідповідності кваліфікаційної характеристики фахівця вимогам ринку професійної праці, роботодавців. Проблема визначення кваліфікаційних вимог ринку праці до фахівців і коректування їх кваліфікаційних характеристик.

- Проблема неадекватності й коректування вмісту навчального плану, робочих програм необхідним компетенціям, відповідно до потреб розвитку ринку праці та регіону.

- Проблема формування контингенту студентів із мотиваційними установками й рівнем професійної придатності, адекватними вимогам вмісту освітньо-професійної підготовки, скоректованою відповідно до потреб суспільства.

- Проблема розвитку системи моніторингу й контролю якості підготовки фахівців, що включає: а) систему внутрішньої оцінки якості підготовки, а саме методи оцінки при вхідному, поточному й підсумковому контролі якості підготовки фахівців; б) систему зовнішньої оцінки якості підготовки фахівців.

- Проблема вдосконалення навчального процесу в напрямі розвитку конкурентних переваг у майбутніх фахівців [5, с. 52].

Є.Н. Гогунов виокремлює найбільш розповсюджені недоліки у формуванні готовності до професійної діяльності, серед яких: шаблонність професійних дій у сфері методичного забезпечення; психологічна невпевненість у своїх можливостях; нездатність до новаторських рішень, страх (боязнь) зробити помилку; знижена мотивація до професійної діяльності, значні переживання; підвищена 
тривожність, надмірна концентрація уваги на собі; визнання власної безпорадності в організації психолого-педагогічного забезпечення навчального процесу або зайва самовпевненість в цьому питанні; відсутність умінь використовувати на практиці засоби і методи психологічної дії, саморегуляції, управління станом і поведінкою тих, хто навчається [2, с. 42].

Дослідження Ю. В. Коваленко свідчить про неготовність випускників фізкультурних ВНЗ на високому професійному рівні керувати процесом фізичного виховання школярів. Він виділяє умови підвищення ефективності професійної підготовки студентів, які освоюють цю спеціальність:

- формування професійної готовності студентів до фізичного виховання дітей шкільного віку, суть якої полягає в єдності мотиваційного (сформованість інтересу й потреби до майбутньої професії, до здорового способу життя);

- когнітивно-діяльнісного (професійні знання, уміння та навички), особистісного (професійно значущі якості особистості), здоров'язберігального (рівень фізичного здоров'я, функціональної підготовленості) компонентів з урахуванням їх взаємодії;

- інтеграція знань загальних основ фізичного виховання й особливостей психофізичного розвитку школярів;

- реалізація специфічних принципів пріоритету особистості майбутнього фахівця, безперервність і багаторівневість освіти, необхідність інтенсифікації навчального процесу, урахування специфіки майбутньої професії [7].

Л. І. Лубишева зазначає, що завданнями спеціальної підготовки майбутніх фахівців у сфері фізичної культури і спорту повинні стати: формування мотивації та інтересу студентів до нових ідей і освоєння передового досвіду; навчання методам пошуку i відбору інформації про інновації; розвиток здатності перенести інноваційний досвід у власну педагогічну діяльність; формування інтересу і здатності до розробки нововведень; навчання основам науково-дослідницької діяльності, організації та проведення педагогічного експерименту; навчання передачі власного інноваційного досвіду [8, с. 166].

О. П. Гришина вказує на значення розвитку мотивів, які спонукають майбутніх вчителів фізичної культури формувати потребу учнів у здоровому способі життя, зберігати і підтримувати у них здоров'я, стає відправним моментом для оволодіння студентами різних типів наукових знань, реалізація яких у практичній педагогічній діяльності сприяє формуванню в учнів досвіду здорового способу життя [4, с. 42].

Аналіз наукових досліджень і методичних публікацій дає змогу констатувати наступне: сучасні вимоги до професійної компетентності учителя, його теоретична та практична підготовка набувають більш вираженого характеру та мають бути спрямовані на формування особистості педагога з такими якостями, які відповідали б наявним вимогам сьогодення і забезпечували успішність практичної діяльності.

Майбутній учитель фізичної культури має бути підготовлений до викладацької, навчально-виховної, науково-методичної та організаційно-керівної діяльності у системі середньої освіти відповідно до отриманої спеціальності. Типовими видами його діяльності $\epsilon$ : навчально-виховна, фізкультурно-оздоровча, спортивна, організаційна та рекреаційно-профілактична робота. Означені вище види діяльності включають: планування процесу фізичного виховання; організацію і проведення уроків фізичної культури; проведення навчально-тренувальних занять, організацію секційної роботи, підготовку шкільних команд до змагальної діяльності; пропагування здорового способу життя та контроль за рівнем здоров'я і фізичної підготовки учнів; підвищення власного професійного рівня, узагальнення та впровадження передового досвіду роботи[6, с. 247].

Реалізація навчальної, виховної та оздоровчої роботи, яка у школі починається з уроків фізичної культури, має своє продовження у позаурочних і позашкільних 
спортивних заходах, критеріями ефективності якої $є$ успішна участь у спортивних змаганнях. Це допомагає активізувати i урізноманітнювати форми урочної та позаурочної спортивної роботи.

Організаційна робота учителя фізичної культури включає у себе підготовку та проведення спортивних вечорів, фестивалів, туристичних екскурсій та походів, підготовки шкільних команд для участі у спортивних змаганнях тощо. Рекреаційнопрофілактична робота вчителя фізичної культури полягає у відновленні та зміцненні здоров'я учнів із використанням фізичних вправ та оздоровчих сил природи (цілющі властивості води, гірське повітря, сонячне проміння тощо).

Для реалізації означених видів діяльності майбутньому учителю фізичної культури необхідно оволодіти наступними вміннями:

- планувати, організовувати, проводити й контролювати навчальнотренувальний, фізкультурно-оздоровчий і виховний процес;

- здійснювати суддівство спортивних змагань з ігрових видів спорту;

- комплектувати навчальні й навчально-тренувальні спортивні групи;

- виконувати функції представника колективу або спортивної команди на змаганнях;

- аналізувати й узагальнювати досвід роботи; здійснювати індивідуальний підхід у процесі фізичного виховання, фізкультурно-оздоровчої й спортивно-ігрової діяльності; організовувати самостійні заняття учнів фізичною культурою, зокрема спортивними іграми;

- раціонально формувати структуру процесу фізичного виховання, фізкультурно-оздоровчої роботи і спортивного тренування;

- ефективно регулювати величину і спрямованість фізичних навантажень для досягнення оптимального оздоровчого ефекту засобами спортивних ігор;

- проводити різноманітні типи уроків та тренувальних занять з учнями різного віку і рівня підготовленості;

- контролювати рівень фізичної підготовленості учнів; вести просвітницьку роботу, спрямовану на популяризацію спортивних ігор та здорового способу життя [13, с. 272].

Для успішної організації змагальної діяльності учителю фізичної культури потрібно оволодіти такими необхідними навичками:

- точно визначати конкретні цілі та завдання;

- правильно планувати підготовку до змагань;

- застосовувати раціональні та ефективні форми їх проведення;

- усувати негативні чинники, що виникають в процесі змагань;

- враховувати та контролювати особистісно-психологічні фактори.

Як свідчить аналіз літературних джерел, дослідження змагальної діяльності у спортивних іграх носить, як правило, односторонній характер [9, с. 115].

\section{Висновки.}

Науковці (П. І. Канівець, С. Н. Гогунов, Ю. В. Коваленко та ін.) вбачають сутність підготовки майбутніх учителів фізичної культури до професійної діяльності не лише у теоретичній, але й у практичній підготовці, коли студенти спрямовують свої зусилля на оволодіння уміннями та навичками застосовувати отримані знання на практиці, на оволодіння уміннями та навичками формулювати професійні завдання та знаходити раціональні способи їхнього вирішення, на оволодіння уміннями та навичками здійснювати вибір оптимальних методів досягнення значних кількісних та якісних результатів професійної діяльності.

На нашу думку, якість освітнього процесу і професійної підготовки студентів ВНЗ є головною ознакою освіти, відрізняє іiі від інших соціальних явищ і видів 
діяльності. Можливість виміру якості дозволяє співвідносити фактичні результати вимірів із заданими стандартами, еталонами, нормами. Також важливий сам процес моніторингу, тобто змістовної інтерпретації фактичних результатів освітньої діяльності, вираження ставлення до них.

Професійна готовність майбутнього учителя фізичної культури виступає як цілісний стан особистості, що виражає якісні характеристики іï спрямованості, свідомості, професійної позиції, іміджу, рівня оволодіння професійно-педагогічними діями.

\section{Список використаних джерел}

1. Боднар А.О. Підготовка майбутніх учителів фізичної культури до олімпійської освіти молодших школярів : дис. ... кандидата пед. наук : 13.00.04 / Аліна Олександрівна Боднар. - Харків, 2016. - 264c.

2. Гогунов Е. Н. Профессионально-психологическая компетентность специалиста по физической культуре и спорту / Е.Н. Гогунов // Теория и практика физическойкультуры. - 2005. - №4. - С. 42-44.

3. Гринченко І. Б. Процес професійної підготовки майбутніх учителів фізичної культури в країнах Європи i в Україні [Електронний ресурс] / І. Б. Гринченко // Педагогічний дискурс. - 2012. - Вип. 12. - С. 103-109. Режим доступу: http://nbuv.gov.ua/UJRN/0peddysk_2012_12_22

4. Гришина Е. П. Формирование готовности будущего учителя физической культуры к созданию и реализации здоровье сберегающих образовательных технологий: дисс. ... канд. пед. наук : 13.00.08 / Е. П. Гришина. - Самара, 2005. $-228 \mathrm{c}$.

5. Канивец П. И. Модели и методы оценки качества подготовки и повышения конкурентоспособности специалистов :дис. ... канд. эконом. наук: 08.00.13 / Павел Илларионович Канивец. - Новочеркасск, 2004. - 230 с.

6. Кашуба А.А. Теоретичні аспекти підготовки майбутніх учителів фізичної культури до організації змагальної діяльності зі спортивних ігор / А.А. Кашуба // Інноватика у вихованні : зб. наук. пр. / Рівн. держ. гуманітар. ун-т. - Рівне: Вид-во РДГУ, - 2016. - Вип. 3. - С. 245-251.

7. Коваленко Ю. О. Професійна підготовка майбутніх фахівців фізичного виховання дітей дошкільного віку у вищих навчальних закладах : автореф. дис. ... канд. пед. наук : 13.00.04 / Ю. О. Коваленко. - Запоріжжя, 2008. - 18 с.

8. Лубышева Л. И. Методология обновления содержания физического воспитания учащейся молодежи / Л. И. Лубышева // Материалы совместной научнопрактической конференции РГАФК, МГАФК и ВНИИФК. - М., 2001. - С. 162166.

9. Мельник А. Ю. Роль змагальної діяльності в підвищенні рівня сучасного волейболу / А. Ю. Мельник, Є. Я. Стрельникова, Т. П. Ляхова // Проблемы и перспективы развития спортивных игр и единоборств в высших учебных заведениях // Сборник статей XI международной научной конференции, 6-7 февраля 2015 года.- Т 2. - Белгород-Харьков-Красноярск :ХГАФК, 2015. - С. 115-118.

10. Попович Н.Є. Формування готовності до самоосвіти майбутніх вчителів іноземної мови: дис. ... кандидата пед. наук : 13.00.04 / Попович Наталія Євгеніївна. - Кіровоград, 2012. - 178 с.

11. Розпорядження Кабінету Міністрів України «Про схвалення Концепції Державної цільової соціальної програми розвитку фізичної культури і спорту 
на період до 2020 року» від 9 грудня 2015p. № 1320-р. - [Електронний ресурс]. - Режим доступу: http://zakon3.rada.gov.ua/laws/show/1320-2015-\%D1\%80

12. Самсутіна Н. М. Професійна компетентність як показник якості фахової освіти майбутнього вчителя фізичної культури / Н. М. Самсутіна // Збірник наукових праць Бердянського державного педагогічного університету (Педагогічні науки). - Бердянськ : БДПУ, 2008. - № 4. - С. 207-210.

13. Свєртнєв О. А. Підготовка майбутнього вчителя фізичної культури до спортивноігрової діяльності в загальноосвітньому навчальному закладі : дис. канд. пед. наук: 13.00.04 / Свєртнєв Олександр Анатолійович. -Полтав. держ. пед. ун-т ім. В.Г.Короленка. - Полтава, 2009. - 330 с.

14. Чернышева Л. Г. Модернизация высшего профессионального образования в области физической культуры и спорта / Л. Г. Чернышева // Педагогические науки. - 2006. - № 7. - С. 95-97.

15. Шандригось В. Проблеми i шляхи підвищення якості професійної підготовки майбутніх учителів фізичної культури / В. Шандригось, Г. Шандригось // Нова педагогічна думка. - 2013. - № 4. - С. 221-223. - Режим доступу: http://nbuv.gov.ua/UJRN/Npd_2013_4_71. 